\title{
Vital Signs LOINC Code
}

National Cancer Institute

\section{Source}

National Cancer Institute. Vital Signs LOINC Code. NCI Thesaurus. Code C83458.

The LOINC code of vital signs data. 